\title{
APLIKASI MULTIMEDIA EDUKATIF GAMES RSBI (RINTISAN SEKOLAH BERSTANDAR INTERNASIONAL) SMP NEGERI 3 MAJALENGKA
}

\author{
Ade Bastian, S.T. \\ Fakultas Teknik, Universitas Majalengka \\ bastiandicaprio@g mail.com
}

\begin{abstract}
Abstracs-State Junior High School 3 Majalengka as Stubs Internasional Standard School has the burden of responsibility for conducting ICT-based education. It needs to be supported by Human Resounces that are reliable, so that learning systems are manufactured by Human Resources that are reliable, manufactured and prepared in accordance with the rules of education and curriculum used.

In presenting the teaching materials are converted into a form of teaching materials animatif, attractive and informative, the need for an analysis and specific research that teaching material are presented in accordance with the wishes of schools and student. So thus the need for this research.

With use traditional guidelines of good graphic design principles, the analysis results in accordance with the tastes of the researcher gave the questionnaire, and resume teaching materials offered by Master Teacher, then these materials can be referred to as the Multimedia Educational Games Applications RSBI SMP Negeri 3 Majalengka is right on target and help schools in implementing ICT-based learning.
\end{abstract}

Keywords : ICT-Based Education, RSBI, Multimedia Educational Games Applications

\section{PENDAHULUAN}

Sekolah Menengah Pertama atau disingkat dengan SMP, merupakan jenjang pendidikan lanjutan bagi siswa Sekolah Dasar atau disingkat SD. Pendidikan dasar mewajibkan seluruh masyarakat untuk menempuh pendidikan dasar sembilan tahun.

SMP Negeri 3 Majalengka sebagai salah satu Sekolah Menengah Pertama yang berada di lingkup kabupaten Majalengka, merupakan SMP favorit. Terbukti dengan peningkatan jumlah siswa pendaftar dari tahun ke tahun yang terus meningkat, sehingga menyebabkan adanya seleksi terhadap siswa-siswa pendaftar. Dengan adanya fakta ini, maka Departemen Pendidikan Nasional Republik Indonesia pada tahun pelajaran 2008 / 2009 menetapkan SMP Negeri 3 Majalengka sebagai Rintisan Sekolah Bertaraf Internasional ( RSBI ) di kabupaten Majalengka.

Dengan demikian, maka perlu diadakannya sistem pengajaran baru yang berbasis ICT, yaitu adanya paket pengajaran yang interaktif dan siap disajikan oleh guru pengajar. Hal ini tentu saja untuk menjawab tantangan di atas dan pencapaian pengajaran yang lugas dan diterima oleh siswa.

\section{IDENTIFIKASIMASALAH}

Berdirinya Rintisan Sekolah Berstandar Internasional ( RSBI ) di SMP Negeri 3 Maja lengka merupakan keputusan dari Dinas Pendidikan
Nasional. Keputusan ini tentunya memerlukan perubahan yang dratis dari seluruh kegiatan, peserta didik, guru pengajar serta sarana dan prasarana. Satu hal yang meenjadi fokus penulis adalah sistem pembelajaran yang menuntut untuk berbasiskan ICT, dimana pembelajaran harus lebih interaktif, menarik dan mandiri.

Pembuatan Aplikasi Multimedia Edukatif RSBI SMP Negeri 3 Majalengka merupakan usaha untuk memenuhi sistem pembelajaran yang diharapkan. Yaitu sistem pembejalaran yang interaktif dan menarik. Dengan demikian, baik guru pengajar dan siswa didik menikmati proses belajar dan mengajar.

\section{TUJUAN}

Adapun tujuan kerja praktek ini adalah untuk membuat suatu paket pengajaran yang berbasis ICT dan interaktif. Dengan demikian, proses pengajaran lebih aktif, interaktif, efektif, menyenangkan dan dapat diterima oleh siswa.

\section{METODE \\ PERANGKAT LUNAK}

Metodologi pengembangan sistem yang digunakan adalah menggunakan paradigma Air Terjun atau Waterfall, yaitu sistem yang dikembangkan merupakan penurunan dari sistem sebelumnya. Tahap-tahap utama dari model ini memetakan kegiatan-kegiatan pengembangan dasar yaitu : 
a. Analisa dan definisi persyaratan. Pelayanan, batasan, dan tujuan sistem ditentukan melalui konsultasi dengan user sistem dimana dalam kasus ini adalah dosen pembimbing dan beberapa guru pengajar di kelas RSBI SMP Negeri 3 Majalengka. Persyaratan ini kemudian didefinisikan secara rinci dan berfungsi sebagai spesifikasi sistem .

b. Perancangan aplikasi dan perangkat lunak. Proses perancangan aplikasi membagi persyaratan dalam sistem perangkat keras atau perangkat lunak. Kegiatan ini menentukan arsitektur aplikasi secara keseluruhan. Perancangan perangkat lunak melibatkan identifikasi dan deskripsi abstraksi sistem perangkat lunak yang mendasar dan hubungan-hubungan antara menu-menu dan sub menu dalam CD Interaktif.

c. Implementasi dan pengujian unit. Pada tahap ini, perancangan aplikasi multimedia direalisasikan sebagai serangkaian program atau unit program. Pengujian unit melibatkan verifikasi bahwa setiap unit atau dalam hal ini menu dan sub menu tiap mata pelajaran, telah memenuhi spesifikasinya.

d. Integrasi dan pengujian sistem. Unit program atau sub menu diintegrasikan dan diuji sebagai aplikasi lengkap dalam menu utama untuk menjamin bahwa persyaratan aplikasi telah dipenuhi. Setelah pengujian aplikasi, kemudian aplikasi multimedia ini diserahkan kepada Sekolah.

e. Operasi dan pemeliharaan. Biasanya (walaupun tidak seharusnya), ini merupakan fase siklus hidup paling lama. Sistem diautoplay dan dipakai. Pemeliharaan mencakup koreksi dan berbagai error navigasi yang tidak ditemukan pada tahap-tahap terdahulu, perbaikan atau implementasi unit sistem dan pengembangan pelayanan sistem, sementara persyaratan-persyaratan baru ditambahkan.

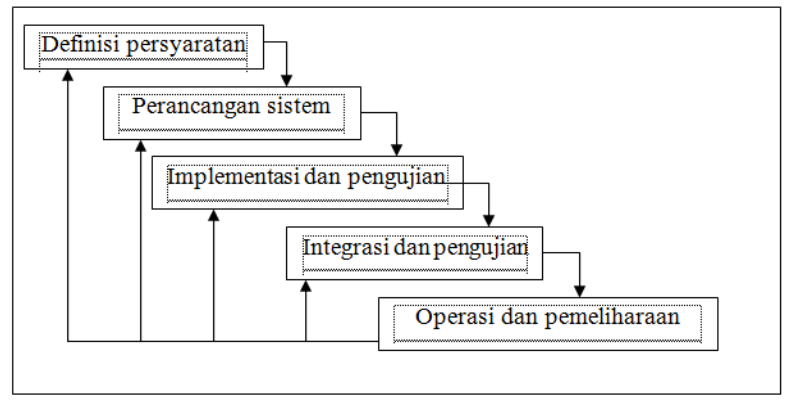

Gambar 1. Paradigma Waterfall

\section{USULAN PENYELESAIAN PERMASALAHAN}

Penyajian materi bahan ajar menggunakan aplikasi multimedia edukatif meliputi menu utama yang memuat sub menu-sub menu yang mendukung diantaranya menu mata pelajaran dan menu peta $\mathrm{cd}$ yang menjelaskan alur isi CD Interaktif. Guru pengajar memilih materi ajar dengan meng-klik tombol mata pelajaran yang akan diajarkan. Kemudian perpindahan tiap slide-nya juga menggunakan tombol. Dalam menyajikannya, guru pengajar membacakan garis besar metari ajar per slide-nya.

Sedangkan siswa didik, mendengarkan penjelasan singkat guru pengajar serta melihat tampilan di layar yang telah disediakan.

Adapun keuntungan-keuntungan yang dapat diperoleh sebagai berikut :

a. Proses belajar menjadi lebih menarik, interaktif dan mandiri.

b. Waktu untuk menyiapkan bahan ajar akan lebih singkat.

c. Siswa dapat belajar lebih aktif.

d. Biaya hemat.

e. Meningkatkan daya ingat siswa didik terhadap materi ajar yang disajikan.

Untuk lebih jelasnya mengenai usulan penyelesaian masalah dapat dilihat pada flowmap usulan dibawah ini :

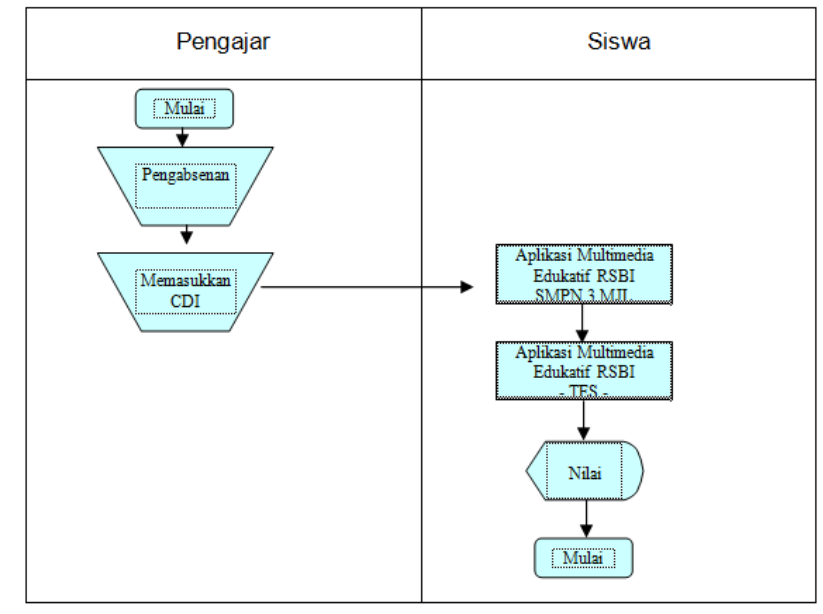

Gambar 2. Diagram Alir Dokumen Usulan

Namun, sifat Aplikasi Multimedia Edukatif yang praktis dapat dimanfaatkan secara lebih aktif oleh para siswa. Hal itu bisa dilakukan dengan membawa aplikasi tersebut ke rumah, dan menjalankan aplikasi multimedia ini di komputer masing-masing. Dengan demikian, proses belajar mengajar lebih mandiri.

Untuk alternatif pelaksanaan belajar menggunakan aplikasi multimedia edukatif , dapat dilihat pada flowmap usulan ke-2 dibawah ini: 


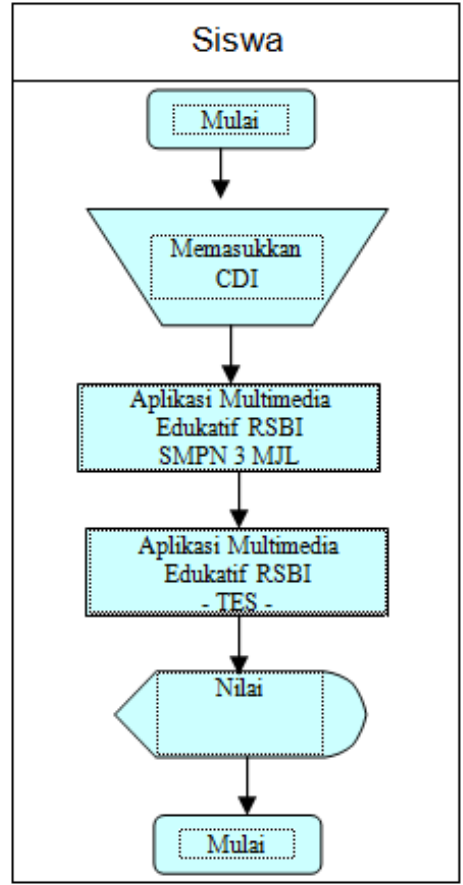

Gambar 3. Diagram Alir Dokumen Usulan ke-2

Dengan demikian, pada pelaksanaannya, penggunaan aplikasi multimedia edukatif memiliki dua cara penggunaan. Yaitu penggunaan secara interaktif di dalam kelas dengan bantuan instruktur seorang guru pengajar, dan cara kedua dijalankan di rumah untuk dipelajari secara mandiri oleh para siswa.

\section{PERANCANGAN}

Diagram aktifitas adalah sebuah diagram yang memodelkan alur kerja sebuah proses bisnis dan urutan aktifitas dalam suatu proses. Proses yang akan di modelkan melalui diagram aktifitas disini adalah urutan proses perjalanan dari aplikasi multimedia edukatif games RSBI SMP Negeri 3 Majalengka. Berikut ini diagram aktifitas level 1:

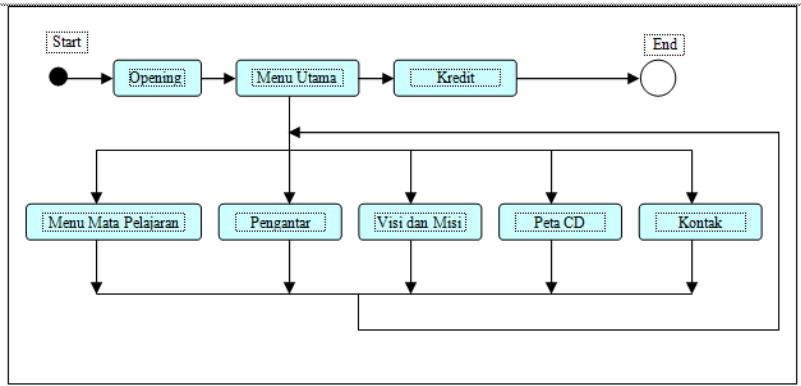

Gambar 4. Diagram Aktifitas Level 1

Diagram aktifitas level 2 merupakan perpanjangan atau perincian dari diagram aktifitas level 1 . Berikut ini diagram aktifitas level 2 aplikasi multimedia edukatif games :

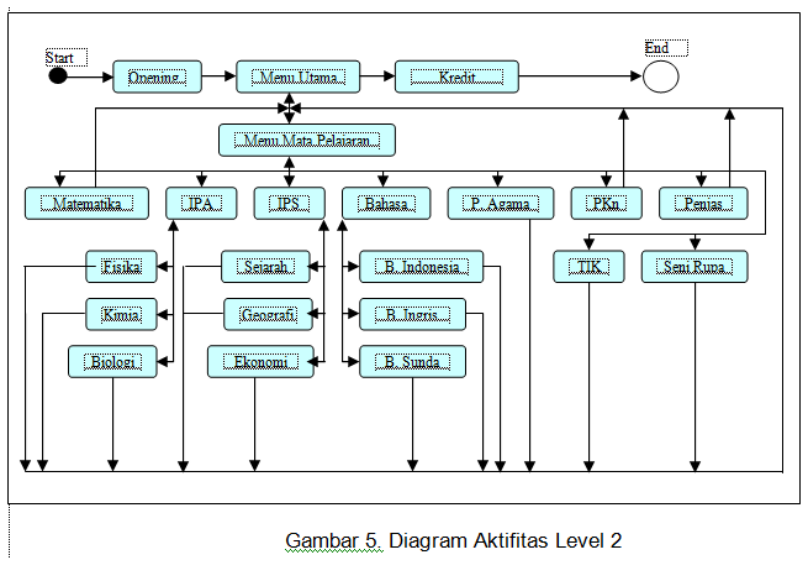

Struktur menu dibuat untuk mempermudah dalam proses pembuatan aplikasi multimedia edukatif games ini. Struktur menu aplikasi multimedia edukatif RSBI SMP Negeri 3 Majalengka memuat 15 menu mata pelajaran yang diajarkan di kelas RSBI serta beberapa menu tambahan yang melengkapi keseluruhan isi aplikasi. Berikut ini struktur menu untuk aplikasi multimedia edukatif games :

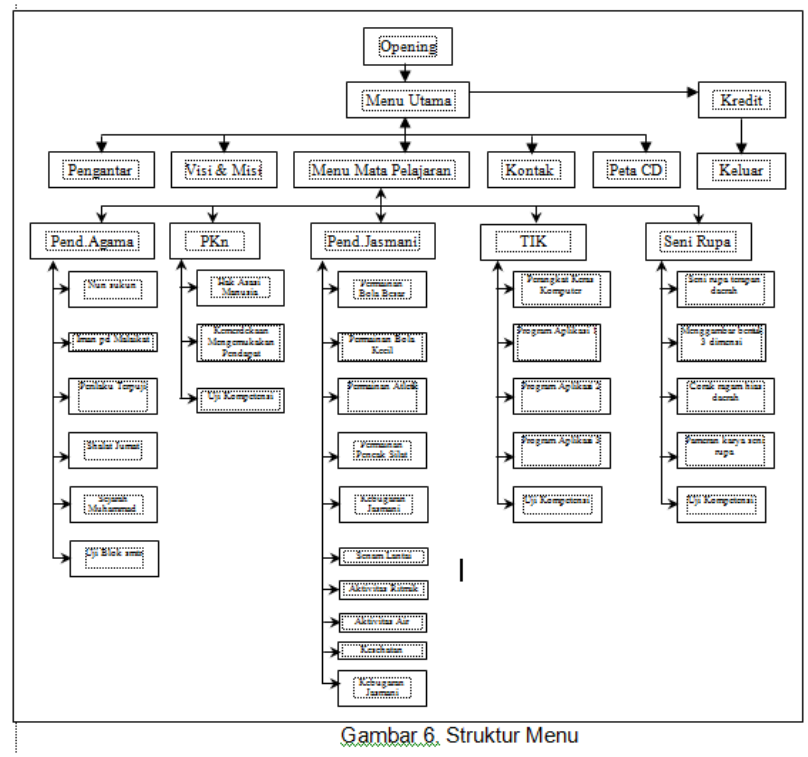

7. IMPLEMENTASI

a. Kebutuhan Perangkat Ke ras (Hardware)

Untuk penggunaan aplikasi multimedia edukatif games dengan output yang maksimal dan lancar, penulis merekomendasikan spesifikasi hardware sebagai berikut :

- Prosessor : intel Pentium / AMD $1 \mathrm{~Gb}$ Rekomendasi $2 \mathrm{~Gb}$

- RAM / Memory : $128 \mathrm{Mb}$ SDR / DDR Rekomendasi $256 \mathrm{Mb}$

- VGA :64 Mb ke atas

- Cd Player : cd Room / Dvd Room 52x

- Monitor : 15" SVGA Color Monitor 
Karena bersifat aplikatif, maka tidak ada suatu software yang harus di instal terlebih dahulu sebelum penggunaan aplikasi ini. Penggunaannya cukup dengan menggunakan fasilitas autoplay pada $\mathrm{CD}$ atau dengan copy dan paste seluruh file kemudian mengaksesnya dengan double klik pada file smpn3mjl.exe. Namun untuk penggunaan sistem operasi, penulis merekomendasikan Windows XP.

Berdasarkan rancangan-rancangan yang telah dipaparkan pada bab sebelumnya, maka dihasilkan implementasi menu-menu untuk aplikasi multimedia edukatif games, sebagai berikut :

\section{b. Imple mentasi Tampilan Menu Opening Pertama}

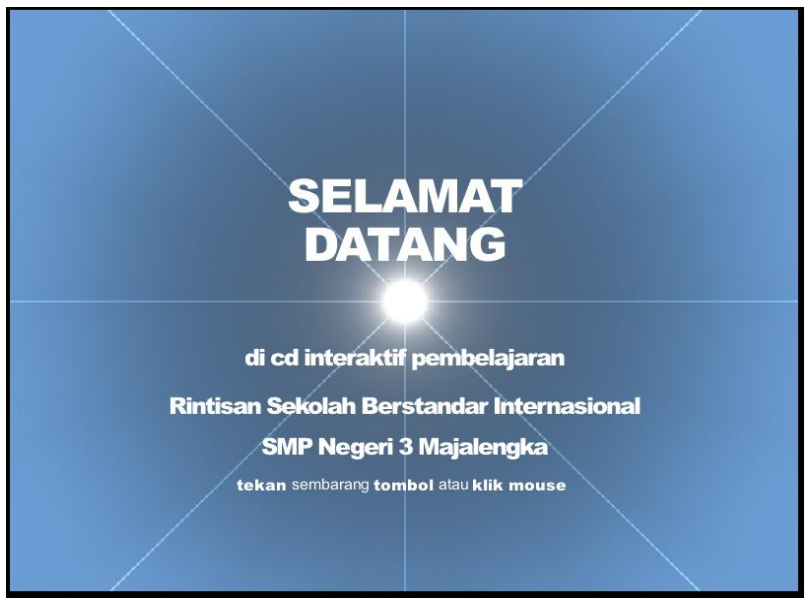

Gambar 7. Tampilan Menu Opening Pertama

\section{c. Impleme ntasi Tampilan Menu Opening Kedua}

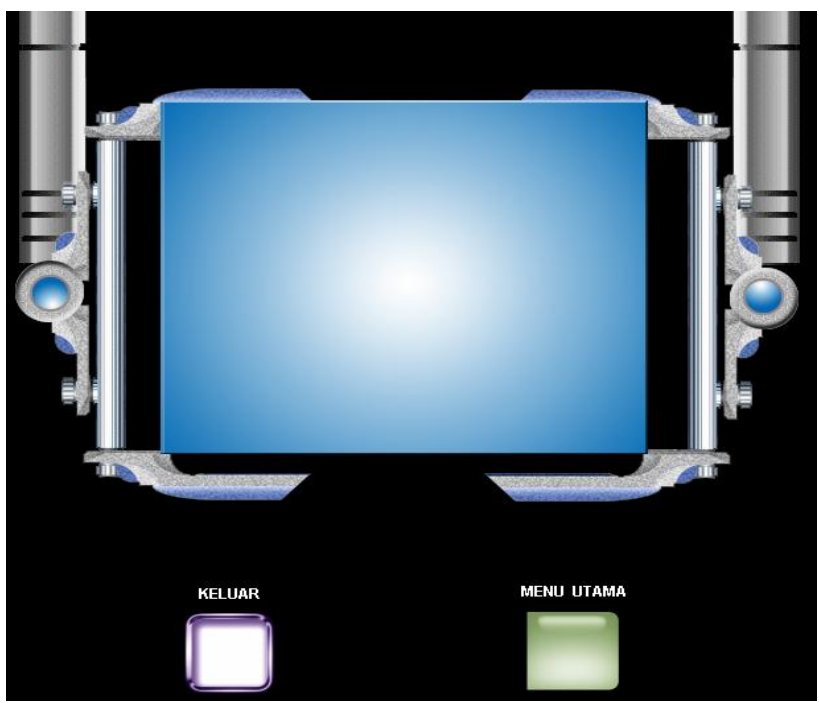

Gambar 8. Tampilan Menu Opening Kedua

\section{d. Implementasi Tampilan Menu Utama}

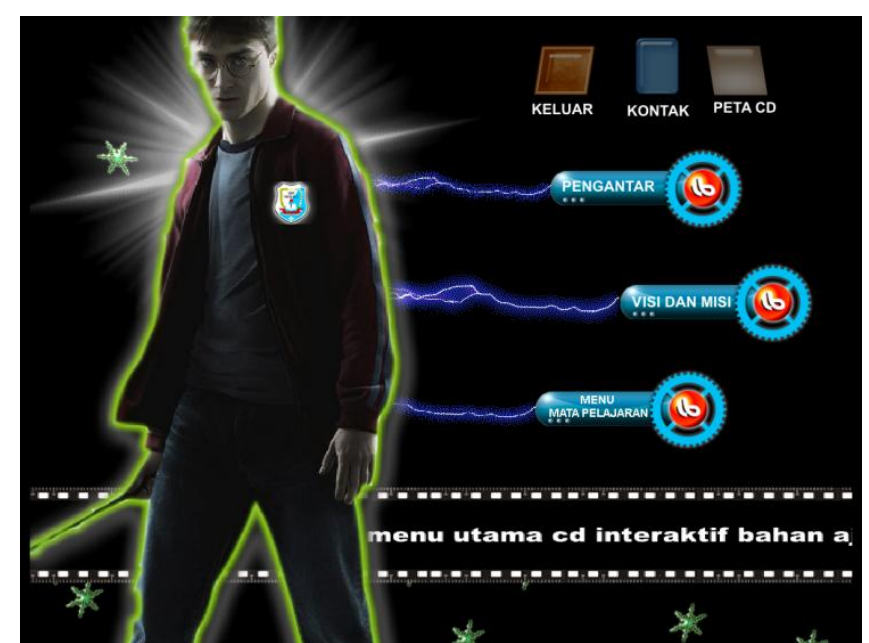

Gambar 9. Tampilan Menu Utama

e. Implementasi Tampilan Menu

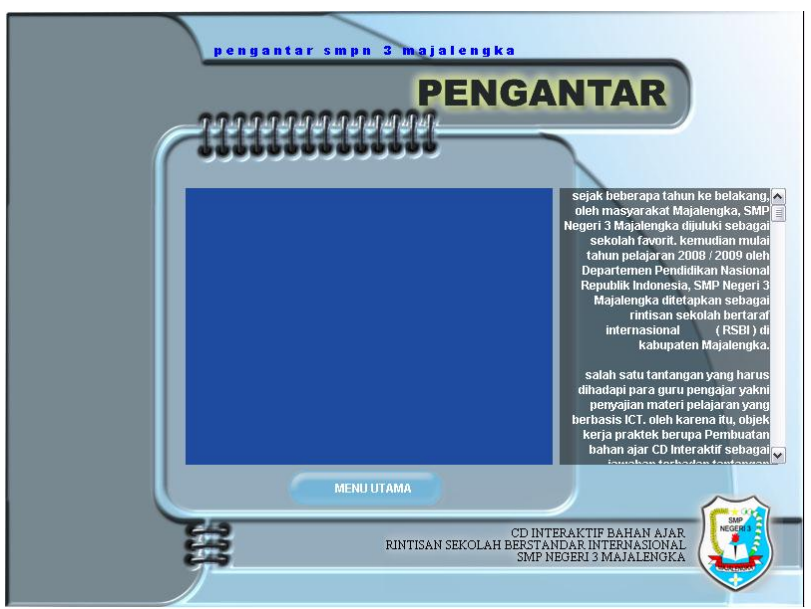

Gambar 10. Tampilan Menu Pengantar

\section{f. Implementasi Tampilan Menu Visi dan Misi}

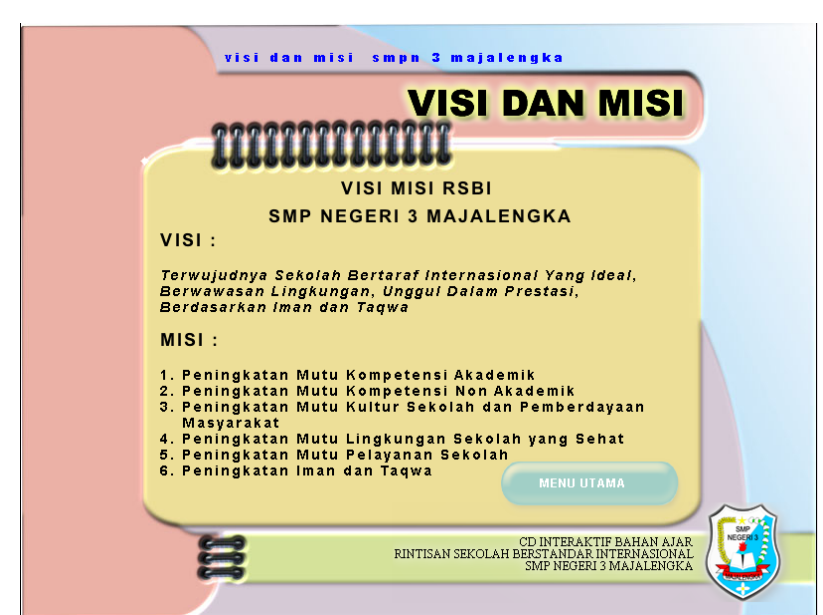

Gambar 11. Tampilan Menu Visi dan Misi

\section{g. Imple mentasi Tampilan Menu Mata Pelajaran}




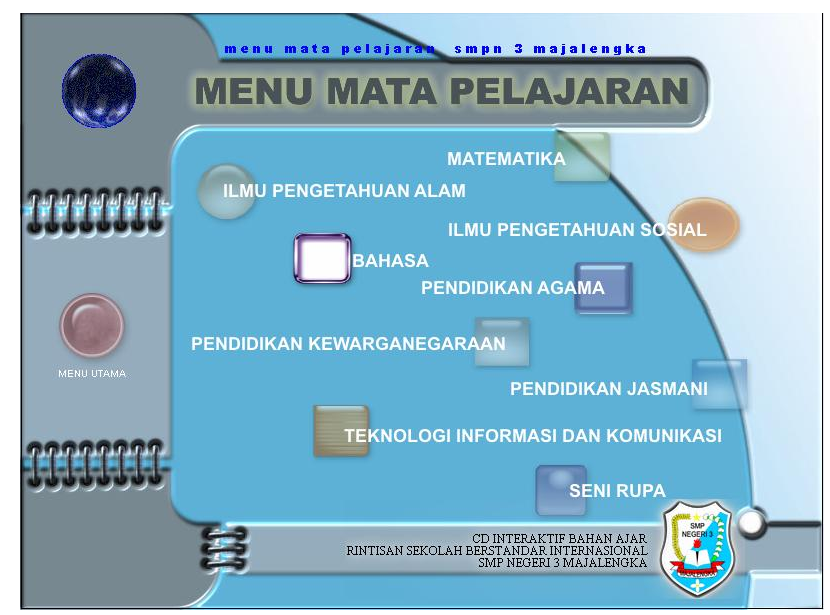

Gambar 12. Tampilan Menu Mata Pelajaran

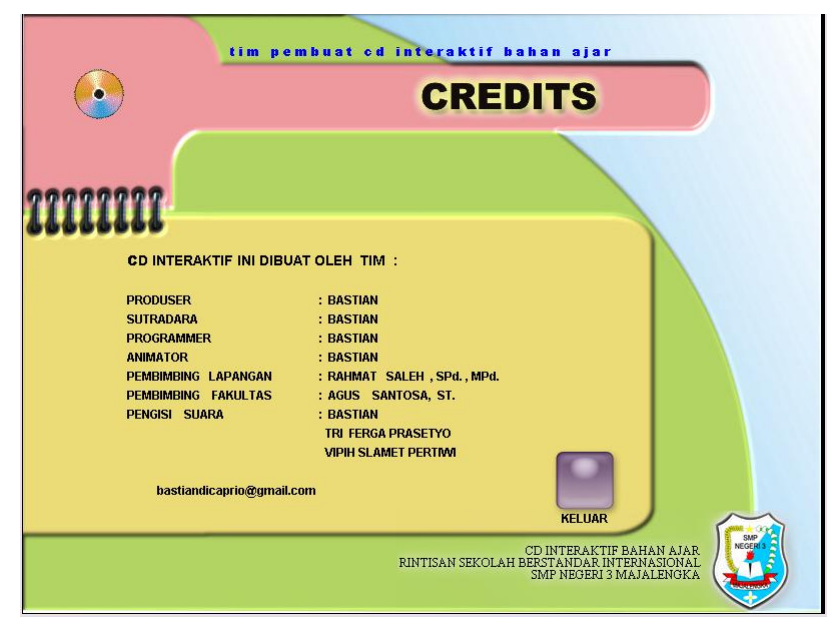

Gambar 15. Tampilan Menu Kredit

\section{h. Imple mentasi Tampilan Menu Peta CD}

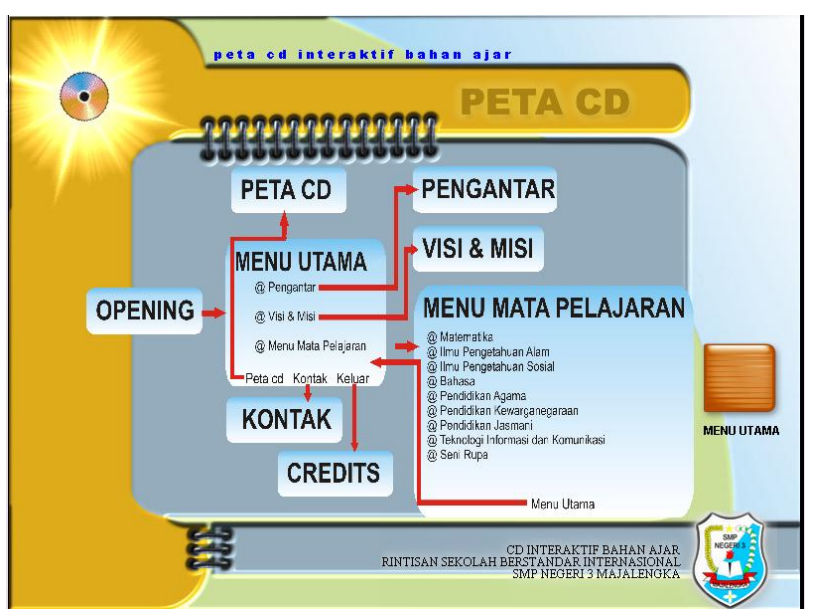

Gambar 13. Tampilan Menu Peta CD

\section{i. Implementasi Tampilan Menu Kontak}

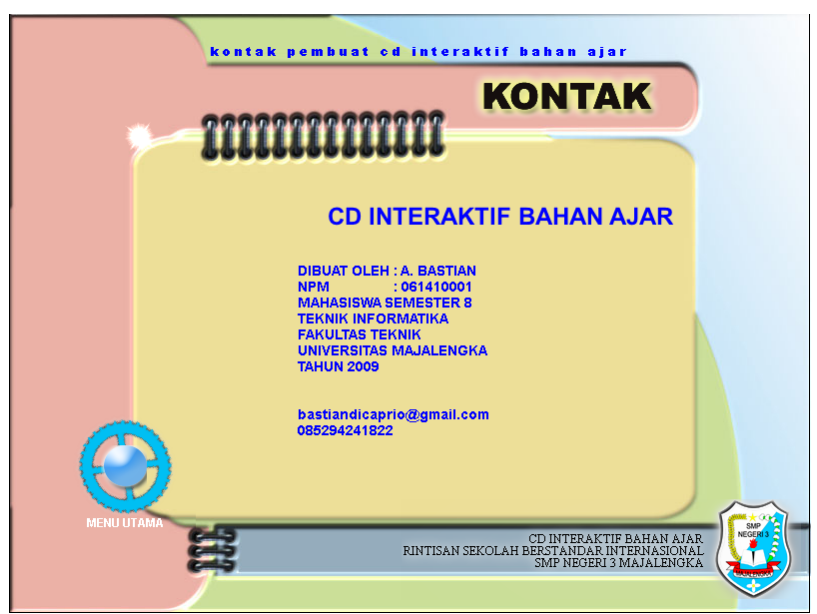

Gambar 14. Tampilan Menu Kontak

\section{j. Implementasi Tampilan Menu Kredit}

\section{PENUTUP}

a. Kesimpulan

Aplikasi multimedia edukatif games RSBI SMP Negeri 3 Majalengka akan diujicobakan sebagai rintisan bahan ajar yang digunakan pada kelas RSBI. Berdasarkan uraian yang penulis paparkan, maka penulis menyimpulkan :

1. Aplikasi multimedia edukatif games RSBI SMP Negeri 3 Majalengka adalah salah satu cara untuk memenuhi tuntutan standar pembelajaran yang berbasis ICT.

2. Dengan diimplementasikannya aplikasi multimedia edukatif games RSBI SMP Negeri 3 Majalengka ini, maka proses belajar mengajar akan berlangsung aktif, interaktif, mandiri serta menarik dan mengena pada peserta didik.

3. Memberikan kepraktisan bagi guru maupun siswa, karena seluruh bahan ajar sudah terintegrasi dalam satu CD Interaktif.

4. Memacu siswa untuk belajar secara mandiri.

\section{b. Saran}

Penulis menyarankan agar pihak manajemen sekolah dapat lebih meningkatkan dukungan dan motivasi kepada para guru untuk menciptakan kondisi pembelajaran dengan memanfaatkan fasilitas pembelajaran berbasis computer.

\section{REFERENSI}

1. [Ad09] Ariyus, Dony. 2009. Keamanan Multimedia. Yogyakarta : Penerbit ANDI.

2. [Hh08] Hendratman, Hendi ST. 2008. The Magic of Macromedia Director edisi revisi. Bandung : Penerbit Informatika Bandung. 
3. [Hh08] Hendratman, Hendi ST. 2008. The Magic of Premiere Pro. Bandung : Penerbit Informatika Bandung.

4. [Na05] Nugroho, Adi. 2005. Analisis dan Perancangan Sistem Informasi Dengan Metodologi Berorientasi Objek. Yogyakarta :Penerbit ANDI.

5. [Ra\&Ar05] Rachmat, Antonius S.Kom. dan Alphone Roswanto, S.Kom. 2005. Multimedia. Universitas Kristen Duta Wacana.

6. [Sa05] Santosa, Agus. 2005. Perancangan Sistem Pengarsipan Kenaikan Gaji Berkala dan Kenaikan Pangkat Pegawai Negeri Sipil di Pemerintah Daerah Kabupaten Majalengka. Bandung : Sekolah Tinggi Teknologi Mandala.

7. [Sm05] Suyanto, M. 2005. MULTIMEDIA Alat Untuk Meningkatkan Keunggulan Bersaing. Yogyakarta : Penerbit ANDI. 